\title{
6 Years of Breast Reconstruction in One Center - An Objective Analysis
}

\author{
Daniela Elena Gheoca Mutu ${ }^{1,2}$, Adelaida Avino $0^{2,3^{*}}$, Laura Raducu ${ }^{2,4}$, Cristina Nicoleta Marina ${ }^{2,4}$, Maria Corina Ștefan², \\ Luminita Florentina Tomescu ${ }^{5}$, Adrian Daniel Tulin ${ }^{1,6}$, Cristian Radu Jecan ${ }^{2,4}$ \\ 'Discipline of Anatomy, "Carol Davila" University of Medicine and Pharmacy, Faculty of Medicine, Bucharest, Romania \\ 2Department of Plastic and Reconstructive Surgery, "Prof. Dr. Agrippa Ionescu" Clinical Emergency Hospital, Bucharest, Romania \\ ${ }^{3}$ Doctoral School, "Carol Davila" University of Medicine and Pharmacy, Faculty of Medicine, Discipline of Plastic and Reconstructive \\ Surgery, Bucharest, Romania \\ ${ }^{4}$ Discipline of Plastic and Reconstructive Surgery, Faculty of Medicine, "Carol Davila" University of Medicine and Pharmacy, \\ Bucharest, Romania \\ ${ }^{5}$ Department of Interventional Radiology, "Prof. Dr. Agrippa Ionescu” Clinical Emergency Hospital, Bucharest, Romania \\ ${ }^{6}$ Department of General Surgery, "Prof. Dr. Agrippa Ionescu” Clinical Emergency Hospital, Bucharest, Romania
}

${ }^{*}$ Corresponding author: Adelaida Avino, MD, PhD Student Assistant Professor

Department of Plastic and Reconstructive Surgery

"Prof. Dr. Agrippa Ionescu" Clinical Emergency Hospital,

7 Ion Mincu, Bucharest, Romania

E-mail: adelaida.avino@gmai.com

\section{Rezumat}

\section{6 ani de experiență în reconstructia mamară - o analiză obiectivă}

Introducere: Cancerul de sân reprezintă cel mai frecvent tip de neoplasm ce afectează femeile din întreaga lume. Reconstrucția sânului după mastectomie a devenit o procedură solicitantă în tratamentul femeilor care suferă de cancer de sân. Rolul major este de a îmbunătăți calitatea vieții pacientelor, ducând la rezultate estetice mai bune. În funcție de tipul de reconstrucție, de complicațiile ulterioare intervenției chirurgicale şi de durata spitalizării, implicațiile financiare variază.

Metode: Studiul nostru a inclus 168 de paciente care au beneficiat de reconstrucție mamară imediată sau întârziată după mastectomie. Am evaluat managementul clinic al fiecărui caz şi am evaluat costul mediu final al tratamentului după reconstrucție, concentrându-ne pe metoda reconstructivă utilizată, complicațiile apărute şi numărul de zile de spitalizare.

Rezultate: Costul total al îngrijirii în operatia de reconstrucție de sân depinde de procedura reconstructivă utilizată, care afectează durata de spitalizare. Cheltuielile depind, de asemenea, şi de materialele utilizate: tipul de implant / expander sau utilizarea $\mathrm{ADM}$. Costurile au fost mai mari la pacientele cărora li s-a făcut reconstrucție mamară folosind un lambou latissimus dorsi asociat cu implant, în comparație cu reconstrucția cu lambou liber. 
Concluzii: Reconstructiia de sân reprezintă un proces crucial în gestionarea pacientelor care au suferit mastectomii în urma cancerului şi presupune costuri variabile, în funcție de metoda reconstructivă aleasă.

Cuvinte cheie: reconstrucția de sân, chirurgie plastică, cancer de sân, radioterapie, complicații, costuri

\section{Abstract}

Background: Breast cancer represents the most common type of neoplasm in women around the world. Breast reconstruction following mastectomy has become a demanding procedure in the treatment of patients suffering from breast cancer. Their major role is to improve the quality of life of women, leading to better aesthetic outcomes. Based on each type of reconstruction, the complications following surgery and the duration of hospital stay, the financial implications slightly vary.

Methods: Our study included 168 female patients who underwent immediate or delayed breast reconstruction after mastectomy. We assessed the clinical management of each of these cases and we evaluated the average final cost of the treatment after the reconstruction, focusing on the reconstructive method used, the complications that occurred and the number of days of hospitalization. Results: The total cost of care in breast reconstruction surgery depends on the type of reconstructive procedure used, which consequently affects the duration of hospitalization of the patients. The expenses also depend on the materials that are used: the type of implant/expander or the use of $\mathrm{ADM}$. Costs were higher in patients who underwent breast reconstruction using a latissimus dorsi flap associated with an implant, in comparison to reconstruction using a free flap.

Conclusions: Breast reconstruction represents a crucial process in the management of women who underwent mastectomies following cancer and presumes variable financial resources, depending on the chosen reconstructive method.

Key words: breast reconstruction, plastic surgery, breast cancer, radiation therapy, complications, costs

\section{Introduction}

Breast cancer, as the World Health Organization reported, is the most common malignancy in women worldwide, with an increasing incidence over the years (1). Therefore, this has been leading to a continuous need for improvement in oncological protocols and reconstructive techniques, in order to offer the patients both a higher survival rate and a better quality of life (2).

Due to highly increasing rates of mortality, thorough medical planning and surgical therapeutic methods are essential to be promptly implemented, in order to control and prevent the disease (3).

Breast reconstruction after mastectomy represents an engaging and challenging issue for both surgeon and patient, due to the required surgical expertise of the operating team and the heightened expectations in terms of aesthetic outcome and satisfaction of the patients (1). The breast cancer type and the radiation adjuvant treatment which may be needed greatly, affect the management and the breast reconstruction methods used. There are two major options following the treatment of breast cancer: immediate or delayed reconstruction of the breast. The optimal timing of the intervention is decided by a multidisciplinary team, which includes a plastic surgeon, an oncologist and a radiation oncologist (4).

Due to the increasing number of reconstruc- 
tive options available for patients after breast cancer surgery, the complications that unfortunately and invariantly occur and the duration of hospital stay, the financial implications slightly vary. Economic evaluation is essential in order to assess the balance between the cost effectiveness of each procedure, the cosmetic outcome and the quality of patient' lives (5).

The purpose of this study was to evaluate the average cost of the procedures, correlated with the different types of breast reconstruction methods.

\section{Materials and Methods}

In our clinical study, we included 168 female patients who underwent breast reconstruction after mastectomy, in the Plastic Surgery Department of „Agrippa Ionescu” Clinical Emergency Hospital, during a six years' period since the beginning of the National Breast Reconstruction Program. All the patients underwent delayed or immediate breast reconstruction after mastectomy for confirmed breast neoplasm. We assessed the clinical management of each of these cases and the algorithm used and we evaluated the donor and reconstruction site complications and the average final cost of the treatment after the reconstruction.

The information was stored into a database and processed with Microsoft Excel 2016. Statistical analysis was performed using the software SPSS 23.0 software and also Microsoft Excel 2016. $\mathrm{p}<0.05$ was defined as statistically significant for the analyzed data.

The results were presented as the mean and standard deviations for quantitative variables and as numbers and frequencies for qualitative variables. In order to study the differences among different types of reconstruction techniques, the chi square test was analyzed for qualitative variables. Multivariate analysis was constructed to identify factors associated with the costs related to different types of breast reconstruction. Covariates for multivariate analysis were selected based on bivariate analyses and included stage of breast cancer, complications and days of hospital stay.

\section{Results}

In our clinic, the management of cases requiring reconstructive techniques following breast cancer surgery implies collaboration between doctors of several medical and surgical specialties. Based on thorough history and examination of the patients, women's preferences for reconstructive methods and their willingness to undergo major surgery and oncological report, we performed $85 \%$ delayed and $15 \%$ immediate breast reconstructions.

Following the protocol used in our department, if the patient has a higher probability of undergoing radiation therapy, mastectomy is initially performed, followed by delayed reconstructive procedures. On the other hand, if the patient is not likely to require radiation therapy, immediate reconstruction is feasible during the same surgery with the breast cancer removal. Out of all the cases, 41 consisted of autologous reconstruction (16 deep inferior epigastric artery perforator, or DIEP, and 25 latissimus dorsi extended flaps), 44 of them consisted of implant-based techniques and the other 83 patients required both autologous and implant-based procedures.

Depending on the stage of the breast cancer, for patients suffering from stage I mammary neoplasm, implant-based reconstruction techniques were performed in $81.25 \%$ cases and expander to implant procedures in $18,75 \%$ cases, whereas, for patients with stage II breast cancer, implantbased reconstructive methods were elected. In cases of stage III disease, DIEP and latissimus dorsi flaps were performed and in one patient with stage IV breast cancer, expander-implant Becker and latissimus dorsi reconstruction was done (Fig. I).

The type of surgical technique was also different in cases where radiotherapy was needed. In patients who required radiotherapy, the reconstruction was mainly done with DIEP free flap and implant associated with 
Figure 1. The type of reconstruction depending on the stage of the breast cancer

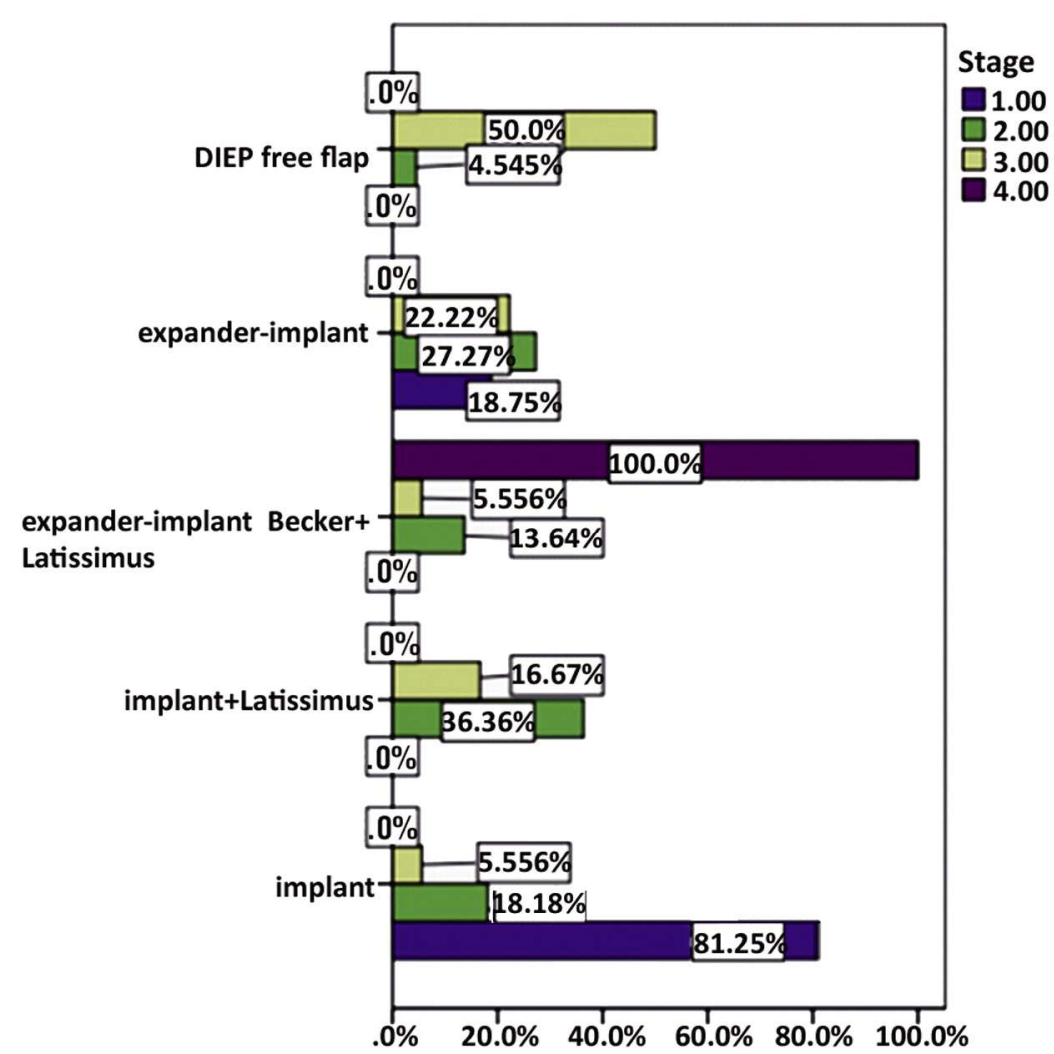

latissimus dorsi flap, whereas implant-only reconstruction was the most frequent procedure in patients who didn't undergo radiotherapy. In the group who directly underwent implant reconstruction, no radiation therapy was preponderantly performed prior to surgery. The association between the need of postmastectomy radiotherapy and the type of reconstructive procedure was noticed as having greater statistical significance $(\mathrm{p}<0.001)$.

The average time between mastectomy and breast reconstruction varied greatly with the reconstructive methods that were used. Implant-based reconstruction required, in average, a 5.7-months-period until the reconstructive procedure, while expander and implant + latissimus dorsi flap reconstructions needed around one year of post-mastectomy time. The longest period between surgeries was found in patients with DIEP free flap or Becker expander-implant + latissimus dorsi flap, with approximately 18 months and 20 months, respectively.
The type of reconstructive procedure affected the duration of the hospital stay, as well. Patients who received implants- only reconstruction remained for 8.6 days in hospital, on average; patients treated with expander-implant or Becker expander-implant and latissimus dorsi flap stayed for about 10 and 12 days, respectively. The longest hospital stay was needed in patients whose breast reconstructions were done using DIEP free flap (almost 14 days) and implant associated with latissimus dorsi flap (15.5 days).

Complications occurred in 45 cases. In 28 patients $(16,2 \%)$ the complications were located at the level of the donor site, while in $10,1 \%$ cases they occurred at the reconstruction site, mostly in patients undergoing immediate direct to implant breast reconstruction.

A significant association between the type of reconstructive procedure and the average final costs was noticed $(p<0.001)$. Costs were higher in patients that underwent breast reconstruction using a latissimus dorsi flap 
associated with an implant $(€ 1.635)$ in comparison to reconstruction using a free flap $(€ 1.487)$, due to the final expenses imposed by the presence of the prosthesis (Fig. 2).

Even though there were only several cases of bilateral prophylactic mastectomy due to the high cost of BRCA mutation test, the costs of immediate reconstruction were much lower than those of unilateral breast reconstruction.

\section{Discussions}

Breast reconstruction after mastectomy following breast cancer represents a challenging and increasingly demanding procedure, due to the gradually higher incidence of mammary neoplasm in women worldwide (6).

In order to restore the aesthetic aspect not only of the operated breast, but also of the contralateral one, the plastic surgeon plays an essential role in reducing the psychological impact of the mutilation caused by mastectomy, that may lead to symptoms of depression and a lower quality of life (7). The surgeon also needs to improve the functional and cosmetic results in terms of symmetry, therefore a reduction mammoplasty or a mastopexy may be required during the same time as the reconstructive procedure (8).

Reconstructive methods vary from an individual to another based, primarily, on patient-related factors, the stage of the disease and the need of postmastectomy radiation therapy.

Another important factor that has to be taken into consideration when deciding the type of breast reconstruction is the adequate timing after mastectomy (9). As Lee et al. in 2015 reported in a study, the moment of the reconstructive procedure is decided mainly by the patient's desire for opting out for a particular type of technique, the plastic surgeon's preference and skills (10) and also by the oncological indication of post-mastectomy radiotherapy (11). Immediate tissue expander/ implant-based breast reconstruction is often avoided when post-mastectomy radiotherapy is needed, due to concerns about high complica-
Figure 2. The average final expenses of each reconstructive procedure

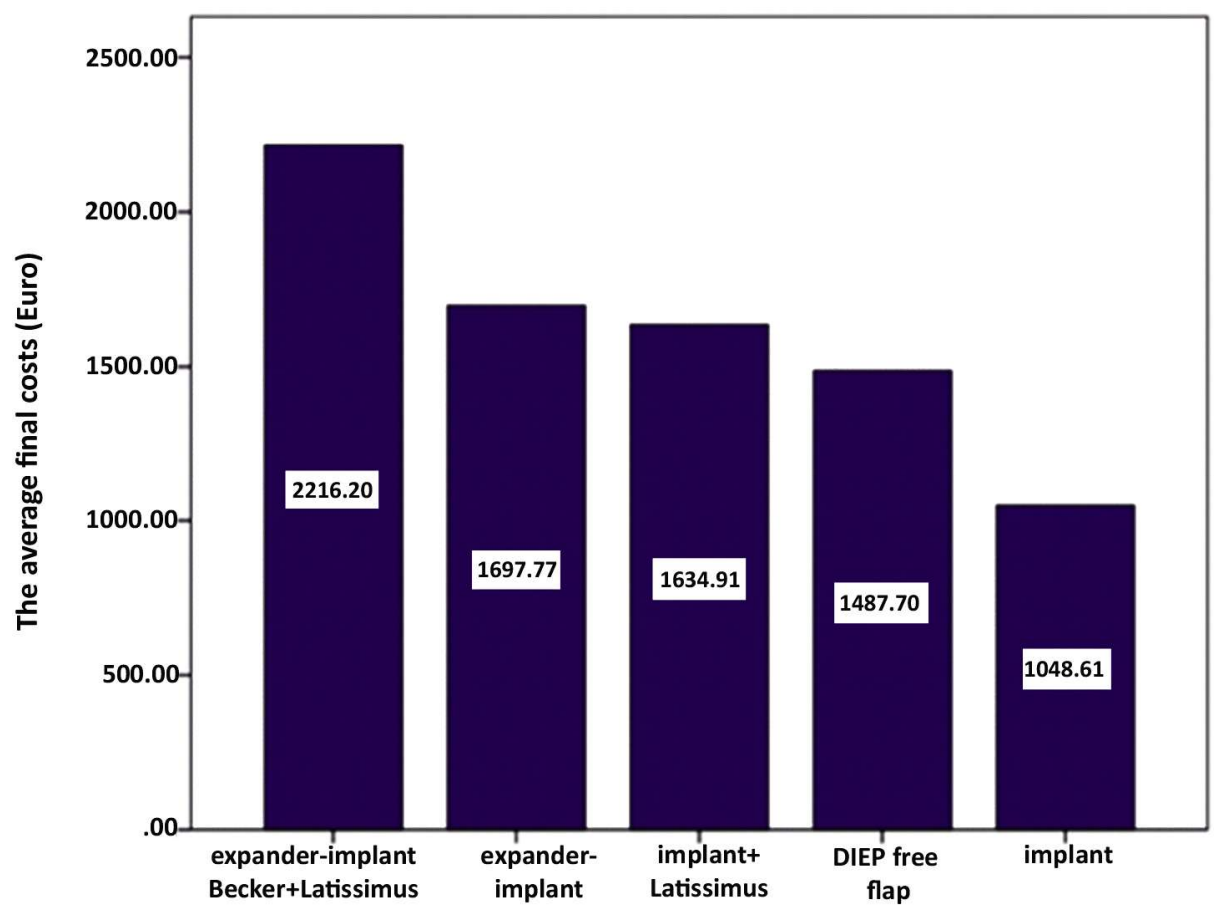

Types of breast reconstruction 
tion rates and poor aesthetic results (5).

All these factors have a major impact on the final costs of the breast reconstruction, that can moderately vary depending on the complexity of each case $(4,12)$. It is important that plastic surgeons are aware of the cost implications of the reconstructive methods and they need to focus on the healthcare expenditure, in order to achieve both optimal financial results and greater aesthetic outcomes $(13,14)$.

Depending on the type of breast reconstruction that was performed, we noted that most complications occurred in the cases where implant and latissimus dorsi flap were used, followed by those where the reconstruction was done using DIEP free flap. By contrast, the procedures least associated with post-operative complications were those that used implant-only and expander associated with implant.

In Romania, the national Breast Reconstruction Program covers up to $€ 1.000$ of the cost of the breast reconstruction procedures. In order to evaluate the expenditure, for each case, an index of complexity is calculated: 1 point of complexity $=€ 300$. For example, for a free flap reconstruction, the index of complexity of 4.85 corresponds to a cost of $€ 1.455$. The amount depends on several aspects, such as the final diagnosis, the secondary comorbidities and the complexity of the surgery. For instance, the average final costs were $€ 2.186$ for patients with stage IV breast cancer at diagnosis, whereas stage III averaged $€ 1.612$, stage II had an average of $€ 1.554$ and stage $\mathrm{I}-€ 1.218$.

The expenses also depend on the materials that are used: the type of implant or the type of expander. Costs were perceivably higher (€2.216) in cases where the reconstruction was done using Becker implant-expander associated with latissimus dorsi flap, compared to cases where expander associated with implant (€1.699), latissimus dorsi flap associated with implant (€1.635), DIEP free flap (€1.488) and implants-only (€1.049) were used.

In cases of insufficient lower pole coverage, expander-implant breast reconstruction can often be supplemented with acellular dermal matrix (ADM), in order to strengthen the inferior part of the breast $(15,16)$. Even though the use of acellular dermal matrix implies increased costs, it leads to safer, less painful reconstructions and better cosmetic acceptability $(17,18)$. The cost of the mesh (around $€ 700$ ) will be added to the final amount.

One major factor that affects the total cost of care in breast reconstruction surgery is the duration of the hospital stay of the patients, which is significantly higher in patients who develop post-operative complications $(4,19)$. In our study, patients who had post-operative complications remained in the hospital, in average, for 16 days. By contrast, complication-free patients only remained in the hospital for 9 days, in average, which resulted in a lower total cost of care for these patients.

Another interesting finding in our study was that even though there were only several cases of bilateral prophylactic mastectomy (due to the high cost of BRCA mutation test), the cost of immediate reconstruction was much lower than that of unilateral breast reconstruction.

We want to specify one of the most important limitations of the study, more exactly the fact that was a retrospective study and the costs of a surgical intervention were lower 6 years ago, but we presented the average data.

Future directions of the study will focus on discovering the best type of breast reconstruction taking into consideration the final costs, but also the aesthetic outcomes.

\section{Conclusions}

Breast reconstruction represents an essential process in the management of women who underwent mastectomies following cancer and implies variable financial resources, based on each reconstructive method. It also plays a considerable role in improving the quality of patients' lives, due to the possibility of reaching acceptable cosmetic results and increased aesthetic satisfaction rates. 


\section{Authors' Contributions}

All authors have contributed equally to the present work and thus are main authors.

\section{Conflicts of Interest}

\section{No conflicts of interest.}

\section{Ethics of Approval}

Local ethical agreement and informed consent of the patient were obtained.

\section{References}

1. Momenimovahed Z, Salehiniya H. Epidemiological characteristics of and risk factors for breast cancer in the world. Breast Cancer (Dove Med Press). 2019;11:151-164. eCollection 2019.

2. Qin Q, Tan Q, Lian B, Mo Q, Huang Z, Wei C. Postoperative outcomes of breast reconstruction after mastectomy: A retrospective study. Medicine (Baltimore). 2018:97(5):e9766.

3. Ghoncheh M, Pournamdar Z, Salehiniya H. Incidence and Mortality and Epidemiology of Breast Cancer in the World. Asian Pac J Cancer Prev. 2016;17(S3):43-6.

4. De Blacam C, Momoh AO, Colakoglu S, Slavin SA, Tobias AM, Lee BT Cost analysis of implant-based breast reconstruction with acellular dermal matrix. Ann Plast Surg. 2012;69(5):516-520.

5. Brennan ME, Flitcroft K, Warrier S, Snook K, Spillane AJ. Immediate expander/implant breast reconstruction followed by post-mastectomy radiotherapy for breast cancer: Aesthetic, surgical, satisfaction and quality of life outcomes in women with high-risk breast cancer. Breast. 2016;30:59-65.

6. Ananthakrishnan P. Lucas A. Options and considerations in the timing of breast reconstruction after mastectomy. Cleve Clin J Med. 2008;75 Suppl 1:S30-3
7. Archangelo SCV, Sabino Neto M, Veiga DF, Garcia EB, Ferreira LM Sexuality, depression and body image after breast reconstruction. Clinics (Sao Paulo). 2019;74:e883

8. Petit JY, Rietjens M, Garusi C. Breast reconstructive techniques in cancer patients: which ones, when to apply, which immediate and long term risks? Critical Reviews in Oncology/Hematology. 2001; 38(3):1040-8428.

9. Avino A, Răducu L, Brîndușe LA, Jecan CR, Lascăr I. Timing between breast reconstruction and oncologic mastectomy-one center experience. Medicina (Kaunas). 2020;56(2):86

10. Lee M, Reinertsen E, McClure E, Liu S, Kruper L, Tanna N, et al. Surgeon motivations behind the timing of breast reconstruction in patients requiring postmastectomy radiation therapy. J Plast Reconstr Aesthet Surg. 2015; 68(11):1536-42.

11. Javaid M, Song F, Leinster S, Dickson MG, James NK. Radiation effects on the cosmetic outcomes of immediate and delayed auto-logous breast reconstruction: An argument about timing. J Plast Reconstr Aesthet Surg. 2006; 59(1):16-26.

12. Razdan SN, Cordeiro PG, Albornoz CR, Ro T, Cohen WA, Mehrara BJ, et al. Cost-Effectiveness Analysis of Breast Reconstruction Options in the Setting of Postmastectomy Radiotherapy Using the BREAST-Q. Plast Reconstr Surg. 2016;137(3):510e-517e

13. Schmitt WP, Eichhorn MG, Ford RD. Potential costs of breast augmentation mammaplasty. J Plast Reconstr Aesthet Surg. 2016; 69(1):55-60

14. Nava MB, Catanuto G, Rocco N. How to optimize aesthetic outcomes in implant-based breast reconstruction. Arch Plast Surg. 2018;45(1):4-13

15. Filip Cl, Berbece S, Raducu L, Florescu IP, Ardeleanu V, Jecan CR. The Prospects of Using Meshes in Imediate Implant - Based Breast Reconstructions, Mater. Plast. 2017:54(3):414-417.

16. Boháč M, Danišovič L', Koller J, Dragúňová J, Varga I. What happens to an acellular dermal matrix after implantation in the human body? A histological and electron microscopic study. Eur J Histochem. 2018; 62(1):2873.

17. Krishnan NM, Chatterjee A, Rosenkranz KM, Powell SG, Nigriny JF, Vidal DC. The cost effectiveness of acellular dermal matrix in expander-implant immediate breast reconstruction. J Plast Reconstr Aesthet Surg. 2014;67(4): 468-476.

18. Margulies IG, Salzberg CA. The use of acellular dermal matrix in breast reconstruction: evolution of techniques over 2 decades. Gland Surg. 2019; 8(1):3-10.

19. Palve JS, Luukkaala TH, Kääriäinen MT. Predictive risk factors of complications in different breast reconstruction methods. Breast Cancer Res Treat. 2020;182(2):345-354. 